\title{
India and the East Asia Miracle
}

\author{
Brent Davis
}

$\mathrm{T}$

The economic development and growth of East Asia over the past half century has been little short of remarkable. To some, such as the World Bank (1993), it is a 'Miracle'. India, by contrast is a composite of admirable achievement, dismal failure and challenges shirked. According to Root (1998), India's admirable achievements include a sustained commitment to democracy, while its failures comprise the absence of any meaningful reduction in mass poverty and the spread of economic and political corruption. The Economist magazine (1997:9) puts it more plainly, describing India as an 'epic tale of wasted promise'.

\section{The East Asian Miracle}

The economies of East Asia have experienced substantial and generally sustained economic growth, development and transformation over the past four decades. A few figures are illustrative: in 1950, Asia accounted for just 19 per cent of world income; by 1992, the share had risen to 33 per cent; and, between 1960 and 1985, real income per capita increased by a factor of four in Japan, Hong Kong, South Korea and Taiwan, and more than doubled in Indonesia, Malaysia and Thailand. Looked at another way, East and South East Asian countries experienced average annual real per capita economic growth rates in the 25 years to 1990 which, except for a number of European countries in the immediate post-war period, were probably unprecedented in human history.

The 'East Asian Miracle' can be distilled to seven core characteristics which set the high performing Asian economies (HPAEs) apart from other developing (and many developed) countries in the three decades to 1990. These were: rapid economic growth and reduced inequality; rapid output and productivity growth in agriculture; relatively higher rates of manufactured exports; earlier and steeper declines in fertility; higher growth rates of investment, supported by higher rates of savings; higher growth rates in human capital; and, higher rates of total factor productivity growth.

While there has been general recognition of the superior economic performance of the HPAEs, there has been much debate over the causes of the 'Miracle'. The World Bank (1993) argues the HPAEs achieved their high rates of economic growth by 'getting the basics right' - that is, by operating sound

Brent Davis, at the time of writing, was a postgraduate student in the Asia Pacific School of Economics and Management at The Australian National University. 
economic policies, and expanding the quantity and raising the quality of physical and human capital.

Macroeconomic management was seen to be particularly good. Economic performance was also unusually stable, including low inflation and high national savings, which encouraged national savings and private sector capital investment, respectively. The HPAEs also recognised macroeconomic crises were very costly in terms of lost economic growth. According to the World Bank (Online1), a single year crisis which reduced economic growth two standard deviations below average growth cost the equivalent of eight years of growth.

International competitiveness was a key economic policy objective, reinforced (after some initial flirtations with import-substitution policies) with trade liberalising, pro-export external policies. Expanding the human capital base also played an important role, although it was the targeting of educational policy and quality rather than the quantity of outlays which made the difference to economic development paths amongst the HPAEs.

Savings, investment and financial market policies were subject to both economic-fundamental and interventionist policies. National savings policies were often interventionist, ranging from rigorous pursuit of high public sector savings (for example, Singapore and Taiwan) to mandatory provident funds (for example, Malaysia and Singapore). Investment was also encouraged by a mix of economic-fundamental and interventionist policies: in the former, by creating infrastructures complementary to private investment; and, in the latter, by applying tax policies which favoured productive investment and holding down the prices of imported capital goods.

Labour market policies stressed promoting, rather than the constraining, the operation of market forces. Key elements of these policies included: ensuring generally weak labour unions, and structuring them along corporate, rather than industry, lines; avoiding generalised minimum wage arrangements; and, ensuring a high degree of wage flexibility in the face of macroeconomic shocks.

While there were many similarities in the policies adopted by East Asian countries, there was no single or uniformly applicable 'Asian model' of economic development and growth. The HPAEs used different combinations of policies at different times to provide the platform for and the stimulation of economic growth, with more rapid accumulation of physical and human capital, efficient allocation of resources, and higher rates of productivity than may otherwise have been the case.

\section{The Indian Malaise}

India at Independence in 1947 was already a semi-industrialised nation with a range of industrial activities, including steel and textiles, which had grown out of domestic investment and largely in response to market forces. It had an active entrepreneurial class, a modest but definite integration into the world economy, a first rate civil service and democratic form of government - a sound platform for strong economic development and growth. 
The 1950s saw a clear movement away from this market-orientation with the embrace of a centralised planning framework as the foundation for accelerating economic growth. The governing Congress Party, and Prime Minister Jawaharlal Nehru personally, preferred the more visible hand of the State to the invisible hand of the market: the socialist way was to play the decisive role in India's production and distribution of material goods.

Under the Nehruvian model of State-directed economic development, the public sector would be positioned at the 'commanding heights' of the Indian economy, and act as a transmission mechanism for State plans which would oversee the flow of investment. As a result, according to Bhagwati (1996:7): 'The government turned from indicative planning to a mechanism for masterminding, with the aid of a stifling licensing system, the production, investment and import decisions in the economy to a degree unimaginable to anyone outside the system ...' In statistical terms, annual rates of real economic growth averaged 3.6 per cent during the $1950 \mathrm{~s}, 3.1$ per cent during the $1960 \mathrm{~s}$, and 3.6 per cent during the $1970 \mathrm{~s}$, all of which are clustered around the 'Hindu rate of growth' of around 3.5 per cent.

India's economic growth per capita in the period 1965-88 reinforced the message, lagging well behind that of most other Asian economies. Its annual average per capita economic growth rate of 1.8 per cent was less than half that of Indonesia and Malaysia (4.3 per cent and 4.0 per cent, respectively), just one-third that of China (5.4 per cent), one-quarter that of Singapore ( 7.2 per cent), and a mere one-fifth that of Taiwan ( 9 per cent).

Economic liberalisation in India started tentatively under the Gandhian Prime Ministership, both mother and son, which included selected, necessary deregulation of key sectors. If the reform programs adopted by Indira Ghandi were 'reform by stealth', and those of Rajiv Ghandi were 'reform by reluctance', then those by Prime Minister Narasimha Rao and his Finance Minister Manmohan Singh following the '1991 Crisis' were 'reform by storm' (Bhagwati, 1993).

India's dual program of stabilisation and structural reform were a crisisinduced response to pressures which had been building up from the late $1980 \mathrm{~s}$. While the first priority was economic stabilisation, the 'Crisis' was severe enough to convince policy makers that more substantial reforms were needed for the longer term.

The '1991 Crisis' manifested itself in the collapse of India's international credit rating, the sharp contraction of foreign inflows from non-resident Indians and the curtailment of the even small level of foreign direct investment. Foreign exchange reserves were down to a mere 2 weeks of imports, while India's credit rating had fallen from $\mathrm{AA}$ to $\mathrm{C}$ minus, with the effective termination of foreign private lending. India was on the verge of bankruptcy, and, according to Bhalla (1995), came very close to defaulting on its debt payments for the first time since Independence.

The stabilisation and liberalisation programs implemented in response to the 'Crisis' were a mix of external and internal agendas: external, under the conditions applied by the International Monetary Fund (IMF) and the World Bank 
in return for the loans sought by the Indian Government; and internal, driven by the pro-liberalisation group within the Indian Government, especially in the higher levels and key sections of the bureaucracy.

The liberalisation program worked basically through a new industrial policy which saw industrial licensing removed for projects, whether for the creation or expansion of capacity, or for product diversification. It also involved the elimination of pre-entry clearance requirements, which were replaced by competition policy-style regulation. Reforms in the trade policy area included delicensing of imports (although replaced with import entitlements linked to export earnings), permitting exporters to maintain foreign currency accounts and raise external credits to finance trade transactions, liberalisation of imports of intermediate and capital goods, and the introduction of a more liberal system of exchange rate management. Foreign investment reforms included an easing of entry requirements, the most notable of which was the announcement of an extensive positive list of industries in which foreign ownership was welcomed. Various performance requirements, such as exporting and technology transfer, were also removed.

While much has been achieved since the 'Crisis of 1991' (including a three year period to 1997 when real economic growth averaged more than 7 per cent annually), influential India-watchers such as Little (1996) have criticised the lack of economic liberalisation since 1995. This slowing reflected, amongst other things, the reluctance of the political leadership to confront powerful vested interest groups, most notably rural producers, the bureaucracy, public sector trade unions, and the small scale industry lobby.

Substantial remaining impediments include still high non-tariff barriers, excessive fiscal deficits, inadequate infrastructure especially for power and transport, distorting (and fiscally expensive) subsidies, and inaction over sick industries, labour reform and inefficient public sector enterprises (Joshi and Little, 1996). The International Monetary Fund (1997) has a comparable list, stressing tackling the fiscal deficit, dealing with infrastructure bottlenecks (in particular, roads, ports and power), greater reform of public enterprises including privatisation, and wider trade liberalisation, emphasising further reductions in tariffs, more rapid elimination of quantitative restrictions on consumer goods, and faster relaxation of reservations for the small-scale sector.

Without doubt, the economic policy settings pursued by the high performing Asian economies and by India were a study in contrasts. While the contrasts were numerous, they can be distilled down to two main elements: while the East Asian economies adopted an outward orientation, India looked inward; and, while the East Asian economies sought to capitalise on markets, India looked to government intervention.

\section{Some Key Explanators of Economic Performance}

By any assessment, there has been no single, uniform driver of the high growth Asian economic performance. Rather, it was a combination of policies, varying 
across countries and even within countries across time. The following section examines three of these (inter-related) policy determinants in more detail: trade policy; foreign investment policy; and industry policy.

\section{Trade policy}

A key element of the growth strategies pursued by most of the HPAEs was a strong orientation towards exporting, although some of these countries flirted with import substitution in the earlier stages of their development. Governments in the HPAEs actively encouraged export development and growth through a clear commitment to integration into the world economy, complementary macroeconomic climates and by offering microeconomic incentives.

Macroeconomic factors included broad economic stability, trade liberalisation and, in a number of cases, a deliberately undervalued exchange rate, while microeconomic incentives focused on export promotional activities and applied across-the-board to any potential exporter. Taken together, the two mutually reinforcing policy settings amounted to an overt 'export push' strategy. International benchmarking meant assessing performance against export targets. Where targets were not met, policy makers sought to determine why and alter policy accordingly. Where import replacement or other policies compromised export success, policy would be changed to the advantage of the latter.

The HPAEs also pursued export complementarity in other policy areas. In industry policy, they permitted easy entry into and exit from manufacturing-export activities, while labour market policy promoted responsive labour markets with the market determining wages, and firms able to hire and fire employees when conditions warranted. In fiscal policy, they imposed relatively low taxes upon exporters.

By contrast, India's trade policy for much of the time between Independence and the ' 1991 Crisis' was based on self-reliance through import-replacement. Imports were subject to extensive quantitative restrictions and/or very high tariffs, and exports were tightly regulated. The import-substitution strategy was intended to encourage industrialisation, fulfil the objectives of self-reliance and selfsufficiency, the reallocation of resources to encourage preferred activities and employment growth, and to provide fiscal revenue. Exports were, at best, an afterthought.

India eschewed actively using the exchange rate to encourage exports (at least until the 1980s), sustained inflexible domestic and external policies which impeded the capacity of business to penetrate competitive foreign markets, protected the domestic market with high tariffs and pervasive non-tariff barriers, and adopted a fundamentally hostile attitude to foreign investment. An important outcome of the import-substitution strategy was an industrial sector which lacked vital export capability. The import-substitution mind-set of industry weakened its capacity to adopt new technologies and develop economies of scale, resulting in inefficient domestic industries, low productivity and poor international competitiveness. Reflecting the pervasiveness of the import-substitution strategy, 
India's share of world exports declined from 2.4 per cent in 1948, to a mere 0.4 per cent in 1981, recovering only slightly by 1990 .

Following the '1991 Crisis', the Rao Government announced a bold program of trade and other policy reforms aimed at increasing exports, and reducing the degree of regulatory and licence control applying to foreign trade. Early trade policy reforms included ending the 'actual user' requirement for the importation of capital goods and components, and permitting established exporters to maintain foreign currency accounts and raise external credits to finance their trade transactions. Import tariffs were reduced from a peak of 300 per cent to 150 per cent, with the top rate on capital goods falling to 80 per cent. Subsequently, the import licensing system was virtually abolished, with almost all capital goods, raw materials, and intermediate products being freely importable, although subject to often high tariffs (the liberalisation did not extend to consumer goods).

While India has achieved much in terms of trade liberalisation, much remains to be done. The Indian Government (Hegde, 1998:1) has conceded there is a need to re-examine the remaining '... complex procedures and unwanted cumbersome regulations to free the exporting community from any possible harassment and also lessen their hassles'.

\section{Foreign investment policy}

Foreign investment has been an important part of the HPAEs superior economic performance. It is not widely recognised that Asia's share of global FDI stock almost doubled, from 7 per cent to 13 per cent, between 1980 and 1994. This FDI had a strong export-orientation, except for FDI into China, with most motivated by the desire to build export platforms (Chia, 1997), and take advantage of close geographic proximity to exploit economic complementarities and differences in comparative advantage.

There was also a strong growth in intra-regional FDI flows. 'Pull' and 'push' factors were both important drivers of the rising intra-regional FDI including notably stronger currencies in North East Asian countries, which caused a loss of price competitiveness for domestic producers who relocated offshore initially lower-end, but more recently more advanced, production. Other important drivers include: the relatively poor economic performance, and policy-introspection, of western industrialised nations; and, the inherent competitiveness of the East Asian developing countries, in particular competitive factor costs, more liberal trade and investment environments, and rapid growth of domestic markets.

The essential policy lessons of the East Asian experience with FDI include the most effective way to encourage worthwhile FDI is to implement policies (in the broadest sense) which generally improve the investment climate in the host country. It also means accepting the role of market forces and trends towards regional integration by removing obstacles to information, trade and investment flows.

By contrast, India has traditionally performed poorly in attracting foreign investment, reflecting the inherent contradictions of government policy and the 
various criticisms of multinational companies, both from supporters of the 'socialist path to development' and local industrialists keen to avoid external competition. The overall policy framework was one of uncertainty, accompanied by an uncongenial environment (Sinha, 1994), to the extent of foreign investment being actively discouraged (DFAT, 1994).

India's inward FDI policy during the 1970s and 1980s emphasised sectoral selectivity, with the Central Government seeking to confine multinational firms to preferred sectors and activities. Benchmarks for new FDI approvals included willingness to enter priority sectors, levels of technology transfer involved and degree of export for subsequent production.

The Rao Government's response to the '1991 Crisis' saw substantial liberalisation of the country's policy towards foreign investment, at least by India's historical standards. Key early liberalisation initiatives included making approval virtually automatic for FDI participation up to 51 per cent of equity in priority areas covering most of the manufacturing sector. A number of sectors previously limited to the public sector were opened to private investment (for example, banking, power, air transport, mining, ports and roads), with the readymade garment industry, previously reserved for small-scale industries, opened to larger business.

While India's foreign investment policy reforms may have been necessary, they do not appear to have been sufficient. According to Kumar (1995), India continues to lag behind competitor Asian nations in its capacity to attract FDI.

Between 1990 and 1995, FDI as a share of GDP rose from near zero to 0.4 per cent of GDP in India, well behind China ( 0.9 per cent to 5.7 per cent of GDP), Indonesia (1.0 per cent to 2.4 per cent of GDP) and Malaysia (5.7 per cent to 7.9 per cent of GDP). In the latter year, India attracted US $\$ 1.3$ billion in FDI funds, while China pulled in US $\$ 38$ billion (Chakwin and Hamid, 1996).

India's relatively protected domestic market and remaining screening procedures for foreign investment are also a deterrent to capital inflows. Other priorities involve dealing with market rigidities and associated relatively high wages in the organised sector, and shortages of hard infrastructure, especially those areas which impede export activity such as seaports (Chakwin and Hamid, 1996).

\section{Industry policy}

Most of the HPAEs have pursued, at one time or another, active industry policies. However, the nature and form of these industry policies varied, although they can be grouped under two generic headings: neoclassical, allowing functional interventions; and structuralist, using selective interventions. The neoclassical approach involved functional interventions, dealing with perceived market failures (for example, government playing a role to fill the gap in providing primary and secondary education) and developing broad-based capital markets without favouring any industry, firm or activity over any other. By contrast, the structuralist approach saw selective interventions with governments favouring 
through, for example, taxation, trade or financial policies, one group of firms, industry or sector: the oft-debated notion of 'picking winners' and/or 'getting prices deliberately wrong'.

Key elements of the wider industry policies pursued by the HPAEs were: support for education, especially science and engineering which facilitated technology transfer; and, encouraging through financial market regulation the allocation of finance away from speculative/less productive activities (for example, real estate) towards those of more productive value (for example, funding plant and equipment). They also had strong export- and competitivenessorientations; stressed the importance of research and development, either through acquisition, adaptation or, later along the development continuum, domestic efforts; and, sought to appeal to foreign capital and multinationals for their capacity to fast-track expansion of the nation's industrial base but also to bring with them superior intellectual property.

The foundation of India's industry policy between Independence and the liberalisations of the 1990s was the Second Five Year Plan, announced in 1956, which committed the country to a socialistic pattern of society as a national objective and to industrialisation based on import-substitution/replacement strategies. The basic objectives of Indian industry policy since the mid $1950 \mathrm{~s}$ were, and to a high degree remain, increasing production in priority sectors, ensuring a regional dispersal of growth, promoting the small scale sector and preventing a concentration of commercial power (Shand and Kalirajan, 1994).

The emphasis of industry policy also involved concentration on capitalintensive projects in heavy engineering, basic metals and petrochemicals, with the public sector taking the 'commanding heights'. Consumer goods were considered of secondary importance and relegated to the small-scale industry sector which was also given a range of fiscal subsidies and exclusive rights to manufacture prescribed products.

India's labour market has been dominated by a complex legal regime of around fifty statutes which cover, inter alia, labour welfare and dispute settlement. This regime is particularly potent in the organised sector, which embraces almost all of the public sector as well as medium to large private sector firms. The labour laws also act as a strong disincentive to growth and development by small-scale firms, as once such an employer hires more than ten people they are deemed to be in the 'organised sector' and exposed to more onerous employment obligations. According to the World Bank (1996), labour retrenchment laws, combined with a restrictive 'exit policy' for industrial firms, make it virtually impossible to restructure, let alone close, ailing public and private sector firms, and constrain India's capacity to attract much-needed foreign direct investment.

Much of the public sector investment in India has been poorly utilised, suffering low capacity utilisation, either perpetual losses or very low rates of return on capital, low contributions to national savings and poor levels of operational efficiency. The annual rate of return on capital for public sector enterprises (PSEs) remained below 5 per cent during the 1980 s, falling to a little over 2 per cent in 1990-91 (Bhalla 1995), while the profit-after-tax-to-net-worth 
ratio for Central PSEs was negligible until the mid-1980s, and has been between 3 and 4 per cent since that time. However, when the significant contributions from the petroleum sector are excluded, the ratio has generally been negative (Mahon Rao, 1996).

Inefficiency was endemic in the Central and State Governments' own PSEs, but was compounded by the policy of successive governments taking over 'sick industries' - that is, firms with sustained losses and negative net worth - in response to political pressure to avoid those businesses going bankrupt and the resulting job-shedding. The annual losses of a selected 60 'sick' manufacturing firms in 1993-94 totalled 1.7 times the value of their net fixed assets. Further, accepting these firms could not be privatised, if the Central Government were simply to close down the firms, the World Bank (1996) estimated domestic savings would increase by 0.3 per cent of GDP. By any measure, India's early strategy of State-led industrialisation as the engine of economic growth and development was a failure.

Reflecting this failure, the ' 1991 Crisis' acted as catalyst for the more liberal 'new industrial policy' of 1991, the most significant feature of which was the effective dismantling of the old pervasive industrial licensing system, and the virtual abolition of government control over the investment and production decisions of enterprises. An important priority for industry policy, and for industry per se, is the reorientation of managerial practices away from those developed and suited to the former restrictive, government-dominated framework, toward those emphasising customer orientation and productive excellence.

\section{The Asian Economic Crisis}

Any assessment of India and the East Asian 'Miracle' cannot allow to go unremarked the so-called 'Asian economic crisis'. Without going into a long and detailed examination of the nature, causes and consequences of the plethora of events which came together, it must be said, while the Asian economic miracle may be tarnished, it is not necessarily over.

The East Asian economies may emerge enhanced by the crisis, if they regard it not as a threat but an opportunity to tackle structural impediments (Garnaut, 1998). Importantly, the fundamental conditions which sustained rapid growth and development of the Asian 'miracle' remain largely in place. These include high savings and investment, the emphasis on education, high quantity and quality of economic infrastructure, deep integration into the world economy and acceptance of a major role for markets.

The Asian turmoil, however, does contain a number of policy lessons for India. These include that restrictions on capital account convertibility and limited exposure to short term foreign debt helped to insulate India from the contagion of the turmoil, although this does not mean India should not move ahead thoughtfully and progressively with further economic liberalisation. The World Bank (Stiglitz, 1998) has argued India should exploit the opportunity to forge a comprehensive development strategy to tackle the major challenges which impede better 
economic performance. This includes improving legal and regulatory processes which enhance the transparency and predicability of rules governing foreign investment.

\section{Explaining the Miracle and the Malaise}

The Asian Development Bank (1997) has attempted to shed some light on the important question of relative contributions to the 'Asian Miracle', in a quantitative sense, by examining the influence of a number of factors in explaining growth differentials of East, South East and South Asia. The factors examined were: initial conditions; policy variables; demography; and resources and geography.

Amongst the main findings of the ADB work were that the greatest contribution to explaining relative per capita growth performance were the superior policies implemented by the East and South East Asian countries compared with those of South Asia, with policy variables explaining fully 2.1 percentage points of the 2.9 per cent per capita growth gap between East and South East Asia, and South Asia during the period 1965-1990. In simple terms, policy matters; and, East and South East Asia did policy better than other developing regions, including South Asia (which, given India's relative weight, can be regarded as a reasonable proxy for that country).

The ADB further sharpened the focus of the 'policy variables' category by examining the relative significance of 25 variables for up to 77 countries clustered into three regions (East Asia, South East Asia and South Asia) for the years 1969 to 1971 and 1989 to 1991 . These variables were grouped into what could be called: trade policy; savings and investment policy; industry policy; fiscal policy; education policy; and social policy. The most significant (at the 1 per cent level) positive individual policy factors explaining East Asia's superior economic performance were found to be: exports as a share of GDP; manufacturing export performance; imports as a share of GDP; domestic savings as a share of GDP; and, years of secondary schooling. For South Asia, the only significant (at the 1 per cent level) positive individual policy factor was agricultural value added to GDP, although secondary education indicators were significant and positive (at the 10 per cent level).

Regression analyses by the author using the World Economic Forum's annual World Competitiveness Reports provide an insight into the main characteristics which business leaders consider important to the international competitiveness of India and many of the East Asian economies. These regressions, under the three policy domains studied - trade, foreign investment and industry policy - seek to identify some of the key individual drivers of competitiveness in each of these policy domains, recognising some data constraints (most notably the limited number of years for which consistent and comparable data are available).

Taken as a whole, the East Asian 'recipe' can be said to comprise (being those explanatory variables which generally produced results significant at the five per cent level): encourage entrepreneurship and innovation in management; 
ensure export credit and insurance is available at a reasonable price to those companies interested in exporting; adopt a welcoming approach to foreign investment; ensure a flexible labour market; recognise the parallel economy can enhance business development; and, ensure venture capital is readily available for business development. In other words; the regression analyses are compatible with the World Bank (1991 and 1993) view: intervene reluctantly, by allowing markets to work unless it is demonstrably superior to intervene; apply checks and balances, by continually subjecting interventions to both international and domestic market disciplines; and intervene openly, with interventions being simple, transparent and rules-based rather than subject to official fiat.

By contrast, the author's regression analyses indicate the Indian framework since 1991 has seen: movement towards economic policies which are adapted to current economic realities; continued acceptance or tolerance of corruption in the public sphere; liberation of a national culture which is open to foreigners; recognition that the entrepreneurial talents and innovation of indigenous management are attractive to foreign investors; the growing credibility of corporations with the broader community; and, more liberal access to venture capital for commerce and industry.

\section{Conclusion}

While there has been much debate about the drivers of East Asian economic development and growth, there can be little doubt its sustained nature relative to developed and other developing countries mean the countries involved stand-out from other comparable nations. The recent turmoil on Asian capital markets and downturns in a number of regional economies do not mean the 'Miracle' has come crashing down. Providing appropriate policy reforms are initiated, the weight of opinion favours the East Asian economies resuming their strong economic performances.

India's sustained commitment to democracy has rightly been described as a miracle in itself. However, the same cannot be said for its economic performance which has been hampered by an ideological commitment to centralised planning, government interventionism and detachment from the world marketplace.

While a range of economic policy reforms of varying ambition have been implemented, substantial challenges must be overcome if India is to liberalise and integrate into the world economy sufficiently to achieve and sustain the higher rates of economic growth necessary to meet its self-expected place in the world.

At the minimum, India needs another group of reform-committed senior Ministers at the Centre, covering at least the Prime Minister, and the Ministers for Commerce and for Finance. Allies within key sectional interests, including business, the bureaucracy and the States will also be important. The motivation and momentum for additional far-reaching reforms must come from within, not be driven by external imperatives such as further fiscal or balance of payments crises.

Taken as a whole, East Asia and India are a study in contrasts: the former driven by integration into the global economy, building on the market, with 
adaptable economic policies; the latter driven by insularity, seeking to command the market, with economic policies framed by ideology. India is undoubtedly a political miracle, through its generally sustained commitment to democracy. India has the potential to become an economic miracle, if it can achieve and sustain a commitment to bold and far-reaching program of economic liberalisation and integration into the world economy. Only then will India's 960 million people find Lakshmi - the goddess of wealth and good fortune.

\section{References}

Agrawal. P. (1997), 'Labour Policy: Striking a Balance', in K. Parikh (ed.), India Development Report 1997, Oxford University Press, Calcutta.

Asian Development Bank (1997), Emerging Asia: Changes and Challenges, Asian Development Bank, Manila.

Bhagwati, J. (1993), India in Transition: Freeing the Economy, Clarendon Press, Oxford.

Bhagwati, J. (1996), 'India: Retrospects and Prospects', K. R. Narayanan Oration, The Australian National University, 23 September.

Bhalla, A. (1995), Uneven Development in the Third World: A Study of China and India, St Martins Press, New York.

Chadha, R., S. Pohit, A. Deardorff, and R. Stern (1998), 'Analysis of India's Policy Reforms', The World Economy 21(2):235-259.

Chakwin, N. and N. Hamid (1996), 'Economic Environment in Asia for Investment', mimeo, Asian Development Bank, Manila.

Chandra, P. and P. Shukla, (1994), 'Manufacturing Excellence and Global Competitiveness: Challenges and Opportunities for Indian Industries', Economic and Political Weekly 26 February:M2-M11.

Chaudhuri, S. (1995), 'Government and Transnationals: New Economic Policies Since 1991', Economic and Political Weekly 6 May:999-1011.

Chia, S. (1997), 'Foreign Direct Investment in South East Asia', in S. Chia and M. Pacini (eds), ASEAN in the New Asia, Institute of South East Asian Studies, Singapore.

Chia, S. and W. Dobson (1997), 'Hamessing Diversity', in W. Dobson and S. Chia (eds), Multinationals and East Asian Integration, International Development Research Centre, Ottawa and Institute for Southeast Asian Studies, Singapore.

Department of Foreign Affairs and Trade (DFAT) (1994), India's Economy at the Midnight Hour: Australia's India Strategy, AGPS, Canberra.

Fry, M. (1996), 'How Foreign Direct Investment in Pacific Asia Improves the Current Account', Journal of Asian Economics 7(3):459-486. 
Fry, M. (1997), 'Foreign Direct Investment in East Asia', in D. Leipziger (ed.), Lessons from East Asia, University of Michigan Press, Ann Arbor.

Garnaut, R. (1998), "The Financial Crisis: A Watershed in Economic Thought About East Asia', Asian-Pacific Economic Literature 12(1):1-11.

Hegde, R. (1998), 'Speech on the Occasion of the Release of the Revised Exim Policy', Directorate General of Foreign Trade, Department of Commerce, Delhi, 13 April.

International Monetary Fund (IMF) (1997), 'IMF Concludes Article IV Consultation with India'. Press Information Notice 97/11, Washington DC.

Joshi, V. and I. Little (1996), India's Economic Reforms, 1991-2001, Clarendon Press, Oxford.

Krueger, A. (1995), 'The Role of Trade in Growth and Development: Theory and Lessons from Experience', in R. Garnaut, E. Grilli and J. Reidel (eds), Sustaining Export-Oriented Development: Ideas from East Asia, Cambridge University Press, Cambridge.

Kumar, N. (1995), 'Industrialisation, Liberalisation and Two Way Flows of Foreign Direct Investments: Case of India', Economic and Political Weekly 16 December:3228-3237.

Little, I. (1996), 'India's Economic Reforms 1991-96', Journal of Asian Economics $7(2): 161-176$

Lloyd, P. (1996), "The Role of Foreign Investment in the Success of Asian Industrialisation', Journal of Asian Economics 7(3):407-433.

Mahon Rao, J. (1996a), 'Manufacturing Productivity Growth: Method and Measurement', Economic and Political Weekly 2 November:2927-2936.

Mahon Rao, J. (1996b), 'Indices of Industrial Productivity Growth: Disaggregation and Interpretation', Economic and Political Weekly 7 December:3177-3188.

Petri, P. (1995), 'The Lessons of East Asian Success: A Primer for Transitional Economies', in S. Naya and J. Tan (eds), Asian Transitional Economies: Challenges and Prospects for Reform and Transformation, Institute for Southeast Asian Studies, Singapore.

Radelet, S., S. Sachs and J-W. Lee (1997), 'Economic Growth in Asia'Harvard Institute for International Development, Cambridge, Mass. (Discussion Papers in Development No 609).

Root, H. (1998), 'India: Asia's Next Tiger?', mimeo, Hoover Institution Essays in Public Policy, Hoover Institution Online.

Shand, R. and K. Kalirajan (1994), 'India's Economic Reforms: Towards a New Paradigm?', Research School of Pacific and Asian Studies, The Australian National University, Canberra (Economics Division Working Papers). 
Shand, R. and K. Kalirajan (1998), 'India', Asia Pacific Profiles, Asia Pacific Economics Group, The Australian National University, Canberra.

Sinha, A. (1994), New Economic Policy of India, Deep and Deep, Delhi.

Stiglitz, J. (1996), 'Some Lessons from the East Asian Miracle', World Bank Research Observer 11(2):151-177.

Stiglitz, J. (1998), 'The East Asian Crisis and Its Implications for India', Address to the Corporation of India, New Delhi, 19 May.

The Economist (1997), 'India's Economy: Survey', Country Survey, 22 February.

World Bank (1993), The East Asian Miracle, Oxford University Press, New York.

World Bank (1996), India: Five Years of Stabilisation and Reform and the Challenges Ahead, The World Bank, Washington DC.

World Bank, (On-line1), 'Economic Growth in East Asia', Economic Policy Forums, <www.worldbank.org/html/edi/edimp/eastasia/ea.html>

The views expressed in this paper are those of the author alone and do not necessarily represent those of any organisation with which he may be associated. 